\title{
REFRAMING DOMESTIC VIOLENCE AS TORTURE OR TERRORISM ${ }^{* *}$
}

\begin{abstract}
This paper focuses on the analysis of the phenomenon of domestic violence and the distinctive features for which is it may be recognized as a specific form of torture and/or terrorism at home. The author provides an overview of the scientific debate among feminist authors on this conception which has given rise to an innovative approach to understanding the concept of domestic violence. Underscoring the substantive similarity of domestic violence with the acts of torture and/or terrorism, the author urges for state action arguing that domestic violence as a form of gender-based violence should be approached by applying the same logic and strategies which are employed in response to traditional torture and terrorism.
\end{abstract}

Key words: domestic violence, torture, terrorism.

\section{Introduction}

Sometime in 1992, my dear, now deceased friend, women's rights lawyer, and law professor colleague, Rhonda Copelon, and I had an extended conversation in which we agreed that, as we were committed to recognizing the sex/gender-specific aspects of domestic violence and its deep connection to women's worldwide inequality, we also were thinking about the merits and legal advantages of broadly reframing the rapidly developing women's rights issue of intimate partner/domestic violence to elicit its commonalities with other well-defined forms of violence - more specifically, torture or terrorism. Rhonda argued for the use of the category of 'torture' and its near relative of 'cruel, inhuman and

\footnotetext{
*isabelmarcus@yahoo.com

** The topic of this article is based on the paper I.Markus "Reframing "Domestic Violence": Terrorism in Home" published in: M.Fineman, B.MyKitiuk (eds.), The Public Nature of Private Violence: The Discovery of Domestic Abuse, Routledge, 1994. pp. 11-36.
} 
degrading' treatment (Copelon, 1994). I found arguments for exploring the category of 'terrorism' (Marcus, 1994). The conversation was a thought-provoking one; it ranged from the content of existing human rights norms to legal procedural considerations that might follow from such a reframing. We concluded by agreeing that we needed to pursue the implications of our respective positions.

At the time, in some countries and in international human rights fora, feminist activists and advocates had made some headway in developing the category of gender-based violence-violence against women because they are women as an unequivocal human rights violation. That violence included rape in all settings from conflict zones to the marital bed, honor killing, and domestic/intimate partner systemic violence (likely to occur in the home, a culturally identified the 'safe' and 'appropriate' place for women). These activists noted that the number of victims of gender-based violence exceeds those of war and of brutal dictatorships. (Copelon, 1994: 292). In 1992, the Committee on the Elimination of Discrimination Against Women published its General Recommendation No. 19, on violence against women. ${ }^{1}$ In 1993, at the Second World Conference on Human Rights held in Vienna, women's advocacy groups succeeded in placing violence against women on the agenda. The Vienna Declaration and Program of Action, generated by the conference, stressed the importance of working towards the elimination of violence against women in public and private life. ${ }^{2}$

As academics and activists, Rhonda and I in our respective teaching and NGO work relied on feminist analyses of domestic violence which rest on premises that "the vulnerability of women as a group to the violence is caused by a combination of (1) traditional news about male and female roles and hegemony which may make it difficult for authorities to oppose violence in a relationship...; (2) the private nature of systemic intimate violence...; (3) the concomitant escalation of extreme violence upon separation; (4) economic difficulties restraining women's freedom; and (5) the acquiescence of the victim's community to the violence." (Meyersfeld, 2010: 124).

We independently had come to the conclusion that a reframing would enhance feminist efforts to relocate the legal issue of domestic violence, which hitherto had been identified as occurring in the private sphere of home and family-a posture that protected perpetrators from state intervention and legitimate the partial or total impunity they enjoyed (Copelon, 1994: 297). Since one of the most important state justifications for inaction was the prevailing culture, which persistently trivialized the violence as the chastisement or disciplining

174 UN Doc.HR/GEN/1 (1992).

2 Vienna Declaration and Program of Action, Section II B, para 38, UNDOC.A/Conf 157/24, 12, July 1993. 
of women (Copelon, 1994: 296), we believed that such a reframing could help to transcend these deeply-rooted cultural protections accorded to perpetrators and assist in the world wide campaign for the transcultural and transnational indictment of domestic violence. Reframing, we believed, could move beyond prevailing many of the simplistically reductionist explanations for the violence to an analysis of the political and cultural context of gender-based power and control in order to generate state action (Marcus, 1994: 34).

In effect, our suggestions of connecting domestic violence to torture or terrorism were not deflections or diversions from the goal of expanding the women's rights canon, but rather directed at a fuller understanding of domestic violence as a social and individual choice to do harm. ${ }^{3}$ We recognized that even though both torture and terrorism are unique in their egregiousness, our purpose was to educate about commonalities as well as sex specific aspects" (Copelon, 1994: 299). Our concern was whether privately inflicted gender violence would be treated unequivocally as a human rights violation and as one giving rise to enforceable as opposed to precatory ${ }^{4}$ state responsibility. (Copelon, 1994: 294-295).

Like other feminist legal theorists, we understood that even as domestic violence occurs worldwide in different settings and cultures, and is affected by race/ ethnicity, class, sexual orientation, disability, and immigrant or refugee status, such violence has universal properties. First, that the violence is connected to 'harmful' masculinity (Anderson, 2008) - social and cultural patterns of conduct and practice associated with gender. Second, that it violates women's dignity, and bodily and psychological integrity. Third, that it often involves intentional conduct. Fourth, that it is practiced with impunity because perpetrators are rarely punished and, in so many cases, there are few, if any, remedies for the suffering inflicted upon the woman survivor/victim. Fifth, that women abused by their spouses/partners are likely to be silent about domestic violence - a testament to the power of patriarchal ${ }^{5}$ culture associated with shaming, stereotyping and stigmatizing those who publicly disclose the violence. Sixth, that women's relationships to society and the state are widely medicated through men and

3 Acts of systemic intimate violence include: punching; shouting; battering; biting; burning; hacking; electrocution; starvation; mutilation; sleep deprivation; forced sexual touching; forced sexual activities with third parties; poisoning; exposure; property destruction; murder, withholding medical care; threats of harm; threats to remove children; threatening to use a lethal weapon; persistent shouting; unrelenting accusations of infidelity; controlling day to day activities; isolation; and threats of suicide. (Meyersfeld, 2010: 115).

4 Precatory is defined as requesting, recommending or expressing a desire for action but usually in a non-binding way. Garner, B. (ed) Black's Law Dictionary, 9th ed. 2009.

5 In ideology and practices, patriarchy, the world-wide dominant governing sex/gender regime, addresses issues of control over the infliction of violence and, when warranted, redress for violence deemed illegal or illegitimate in law or cultural practice. 
patriarchy constitutes men as a parallel state in many women's lives (Copelon, 1994: 299). Seventh, that the worldwide incidence and frequency of domestic violence are 'dark numbers'. ${ }^{6}$ (Marcus, n.d.).

In 1994, Rhonda Copelon wrote a signature article "Recognizing the Egregious in the Everyday: Domestic Violence as Torture". My essay "Reframing "Domestic Violence": Terrorism in the Home was published in the same year in a volume discussing the public nature of private violence.

In 2014, twenty years after Rhonda and I had written our respective articles, I decided to revisit them. Fully aware that in the interval between our conversation and the present, an enormous amount of scholarly and activist work at domestic, regional and international levels has enriched our understanding of domestic violence (or intimate partner violence) I asked myself several questions. What can be learned by revisiting these two articles, written in a different period when domestic violence, though integrated into the women's rights canon as women's right to be free from gender-based violence as well as other violence, was still a contested subject in the broad international human rights canon? Were our efforts ultimately mere symbolic gestures generated by the frustration of hearing domestic violence normalized, naturalized, mocked, disregarded, dismissed, or ignored in popular discourse as well as in legal system proceedings?

\section{Discussion of the Literature}

\subsection{Domestic Violence, Torture, and Terrorism}

Strategically, Copelon's reframing of domestic violence as torture or cruel, inhuman or degrading treatment had the advantage of recognition under an international human rights legal umbrella - the making of the International Convention Against Torture and other Cruel, Inhuman or Degrading Treatment or Punishment ${ }^{7}$ made torture "non-derogable". ${ }^{8}$ In addition, torture has as an extensive historical pedigree replete with admittedly chilling details of various inventive practices in different societies. Although the drafters of the international UN Convention Against Torture and the Inter-American Torture Convention ${ }^{9}$ did not have gender-based violence in mind, they did expand the concept of state involvement in torture beyond active complicity to include passive involvement in privately inflicted torture including individual violence (Copelon, 1994: 297).

6 In the socialist countries of Eastern Europe, phenomena known to exist but unrecorded or undocumented were called dark numbers.

7 The International Convention Against Torture and other Cruel, Inhuman or Degrading Treatment or Punishment.

8 Not respectable or abrogatable by later law to limit the utility and force of a provision.

9 Inter-American Convention to Prevent \& Punish Torture OAS/Serv. L/V/I.4rev (2000). 
Both forms of state involvement, Copelon argues, are "broad enough to embrace the failure of government to redress domestic violence (Copelon, 1994: 355). In her analysis, domestic violence as torture encompasses a broader range of cases than servitude which is outlawed under international law. Conversely, domestic violence of lesser severity clearly qualifies as cruel inhuman and degrading treatment which, in human rights law, encompasses less severe forms of (official) violence (Copelon, 1994: 298). The distinction between torture and domestic violence does not lie in the severity of the experience or the tendency to differentiate physical and mental brutality. It flows from the different degrees to which society recognizes both physical and psychological brutality and suffering in the two (private and public) contexts complicated by gender (Copelon, 1994: 324325). Her primary goals are to challenge the assumption that intimate partner violence is a less severe and terrible form of violence than that perpetuated by the state (Copelon, 1994: 352) and to trigger a range of state responsibilities. She seeks to determine whether torture and domestic violence are "equivalently heinous" (Copelon, 1994: 308).

She recognizes that understanding the battery and sexual abuse of women by their intimate partners-perhaps the most common and dangerous form of gender-based violence-as torture, thereby giving rise to obligatory international and national responsibilities, is a 'hard case' from the conventional human rights lens. But, it is an obvious one from women's experience (Copelon, 1994: 295). Consequently, she embarks on a well-developed comparative analysis examining the methods, goals, context, and effects of torture and of domestic violence. She is mindful of the caveat that just as torture is affected by differences in political, social, economic, and gendered contexts, so, too, in domestic violence women are marked by differences (racial or ethnic, class, culture and sexuality) (Copelon, 1994: 299).

Torture involves intentional infliction of pain against the will of the victim (Copelon, 1994: 315). It, thereby, ascribes culpability to the aggressor (Copelon, 1994: 325) - either the state through its agents or non-state actors using torture in conflict situations. In her review of international legal standards concerning torture, she notes that individual malice is not necessary and loss of control is not exculpatory (Copelon, 1994: 328). The use of torture is an abuse of power and an offense against human dignity (Copelon, 1994: 320) regardless of whether the contention is that its purpose is to elicit information (Copelon, 1994: 331-333), to punish, (Copelon, 1994: 333-337), to intimidate (Copelon, 1994: 337-339), for any reason based on discrimination of any kind (Copelon, 1994: 339-340), or to obliterate the personality or diminish capacities (Copelon, 1994: 341). So, too, is domestic violence an abuse of power for a profoundly similar variety of reasons. In both instances, these purposes violate human rights norms. Therefore, she 
concludes, the application of Convention Against Torture to domestic violence is appropriate and warranted. ${ }^{10}$

Fourteen years after Copelon published her article, the second thematic report ${ }^{11}$ of the Special Rapporteur on Torture to the UN Human Rights Council has authoritatively categorized domestic violence as a form of torture. It confirms that the purpose element requirement is always fulfilled in gender-specific violence against women which is inherently discriminatory ${ }^{12}$ and that the continuum of harm is a process.

In "Reframing Domestic Violence: Terrorism in the Home," my analysis develops the commonalities between domestic violence and terrorism. Terrorism, like torture, also is widely condemned in the international human rights canon. But, it is not the subject of a treaty instrument. ${ }^{13}$ It encompasses collectively oriented strategies and practices of coercive violence on targeted populations to generate high levels of public anxiety. Copelon refers to family traditions of punishing disobedience and disciplining by loss of liberty (both integral components of the rationale for domestic violence) as a culture of terror (Copelon, 1994: 293). In later domestic violence literature, domestic violence is characterized as 'terroristic control' to underscore the scope of the control tactics used by the perpetrators of the violence. (Johnson, 1995: 285-86).

I argue that terrorism relies on three fundamental tactics to terrorize individuals (and populations) and, thereby, enhance perpetrators' credibility: unannounced and seemingly random, but, actually, calculated attacks of violence; psychological as well as physical warfare aimed at silencing protests and minimizing retaliatory responses from the targets of violence; and the creation of an atmosphere of intimidation in which there may be no truly safe place to which the targets

10 Copelon also considers arguments for domestic violence as an independent human rights violation given its historic invisibility trivialization, particular character and effects (360) and for law gender-based violence as jus cogens which embraces values of supreme, overriding and fundamental importance to the international community thereby taking precedence over treaties to the contrary, and being non-derogable (p. 365-367).

11 UNHRC Report of the Special Rapporteur on torture and other cruel, inhuman or degrading treatment or punishment. Manfred Novick: Promotion and Protection of all Human Rights, Civil, Political, Economic, Social and Cultural Rights Including the right to Development (15 January 2008) UNDOC A/HRC/7/3.

12 Special Rapporteur on Torture, 2008 Report, para 68.

13 The U.N. has produced a number of General Assembly resolutions on terrorism Including UN Global Counter Terrorism Strategy UNGAOR $65^{\text {th }}$ Session, Agenda Item 150, UN Document A/Res/65/297 8 September 2010 and Measures to Eliminate International Terrorism UNGAOR 65 $5^{\text {th }}$ Session Agenda Item 107, UN Document A/Res/65/34 6 December 2010 'with particular alacrity and consistency since the $9 / 11$ terrorist attacks. 
can escape - thereby making it difficult to judge when and whether targeted individuals are safe or at risk. Personal identity and human connection are deeply compromised; they are replaced by a widespread sense of insecurity, passivity, and defeatism (Marcus, 1994: 31-32).

That said, not all persons, who become targets of terrorism, respond in similar ways or even in a consistent manner over time. Nor are conventional general categories of class, race, or ethnicity accurate predictors of individual responses to the violence. Moreover, characterizing the targets of terrorism as either only victims or only resisters risks overstructuring or overdefining them. Some targets may respond with acts directed against the perpetrators of the violence; other targets may consider their very survival as a challenge to the terrorism; yet others may succumb to understandable feelings of defeat and denial (Marcus, 1994: 32).

I contend that there are striking parallels and similarities between terrorism as a strategy used to destabilize a community or society consisting both of women and men, and domestic violence abuse perpetrated against women. Violence against women in intimate partnership relationships is designed to exercise and maintain domination and control, to enhance or reinforce advantages, and to defend or maintain privileges. As targets of domestic violence, many women live in a world punctuated by violent, traumatic and/or catastrophic events, some of which are predictable and others unpredictable-tailored by the perpetrator to the domestic intimate context. These events include threats and humiliation, stalking, surveillance, coercion, and physical or psychological violence. Whether that violence is identified as the imposition of discipline, as a strategy of family governance, or as an act of the assertion of masculinity, women can be kept in their culturally and socially designated 'place' as well as threatened with or actually lose their social attachments. For many victim/survivors the perpetrator often appears to be omnipotent and omniscient.

"Just as persons caught in situations of politically inspired terrorism display a range of responses to the fear and tragedy it generates, so too, women whose experience in intimate partnering situations is marked by violence demonstrate a variety of behaviors and coping mechanisms for their situation." (Marcus, 1994:33). That said, the reaction to such traumatic or catastrophic events experienced by many targeted women is more than fear for their immediate safety or the safety of their children. The trauma of the violence governs, guides, or influences their actions and decisions. In such situations, survival becomes a form of resistance to domestic violence terrorism (Marcus, 1994: 32-33).

Unlike targets of politically inspired terrorism or torture, however, women, who are targeted in domestic violent relationships, often do not elicit sympathy or 
respect for the oppression they face. All too often, there is a conceptual shift to a focus on the nature and extent of their "provoking" the violence and abuse. This shift is of crucial significance. It disconnects the violence from the social, cultural, economic, and political context of sex-gender domination and subordination. Instead, abused women become the incarnation of prevailing gender stereotypes, such as "nagging bitch," a woman with a "bad attitude," or a castrating female" (Marcus, 1994: 33).

\section{Analysis}

If one accepts the arguments in the previous section of this paper that domestic violence appears to share similar properties with torture and/or terrorism, the next step is to assess the utility of these broader human rights categorizations for the major actors involved with the violence - victim/survivors, perpetrators, and the state. Here similarities and differences among torture, terrorism, and domestic violence are relevant and important.

Insofar as the victim/survivor is concerned, both torture and terrorism are useful categories in providing heightened public recognition not only to the levels and extent of physical pain and suffering, but also to psychological suffering and damage as well as other forms of coercion. Arguably, given the condemnation of both torture and terrorism as reprehensible forms of violence, recognition of their similarities and connections to domestic violence may assist in capturing public attention to domestic violence in its broader political context. Such recognition may enable us to pay closer attention to victim's voices and stories.

That said, for the victim/survivor there are differences between torture/terrorism and domestic violence. Though torture and terrorism can be imposed on both sexes, in 'traditional' torture situations, men are much more likely to be the targets and, thus, the preponderance of victim/survivors. In domestic violence situations, however, an overwhelmingly disproportionate number of women are the victim/survivors. ${ }^{14}$

In domestic violence situations, the perpetrator seeks to establish his dominance not only by terrorizing the victim but also by shaming her and degrading her in the eyes of others, so that she will be stigmatized and scorned should the crime be disclosed. (Herman, 2005: 200-201). Whereas, victims need social acknowledgement and support, in legal proceedings, should they seek redress, they endure a public challenge to their credibility. (Herman, 2005, 202).

14 See Council of European Convention on Preventing and Combating Violence Against Women and Domestic Violence, Istanbul, 11v. 2011 Art. 2.1 Scope of the Convention. 
In addition, unlike domestic violence situations, where gender-inflected provocation is often attributed to the victim/survivor as a culturally accepted mitigating circumstance or explanation, torture and terrorism do not generate such excuses (Copelon, 1994: 361).

Insofar as understanding the status and actions of perpetrators of domestic violence is concerned, both torture and terrorism are useful categories. In both, men are overwhelmingly the perpetrators of the violence. The perpetrators' acts of violence reveal the deliberate intent to control and coerce the victim(s) to conform in designated ways, to set an example, and to send a warning of the risks individuals run by failing to meet perpetrators' desires, requirements, and demands. Likewise, the ample domestic violence literature discusses strategies of control and coercion indicative of perpetrators' intent. In addition, in traditional torture and terrorism, perpetrators are not deterred by existing laws and legal systems. Given the contemporary extent and frequency of domestic violence, the same logic may apply to domestic violence perpetrators in many states, even those with laws on the books ostensibly punishing the violence. (WHO, 2002).

Insofar as the role of the state in responding to domestic violence is concerned, torture or terrorism can be useful categories as well. Until now, however, they are not well integrated into political/legal discourse. Whereas torture and terrorism are highly politicized categories encompassing perpetrators' accountability for their actions and consequences, until recent times, domestic violence has been a depoliticized category enabling custom to prevail and avoiding purposive gender-based dynamics of domination and subordination (Copelon, 1994: 32829). Unlike torture and terrorism, widely perceived as fundamental violations of individual and communities, gender-based domestic violence still is widely excused, thereby feeding men's sense of entitlement, and the victim's sense of culpability. (Copelon, 1994: 362). There is, however, growing recognition of the need for state action ${ }^{15}$ to protect victim/survivors and punish perpetrators by criminalizing domestic violence, providing civil remedies such as orders of protection and other safety measures, and acting with due diligence to effectively implement the law so that victim/survivors can begin to trust the state. (Marcus, 1994: 32-34).

Torture or terrorism by state agents can be stopped; torture or terrorism by non-state perpetrators can be eliminated through negotiations or more drastic militarized state action. Neither of these strategies work for domestic violence which is based on deeply rooted sex/gender inequalities.

15 In Opuz v. Turkey (app.no.33401/02 (ECHR9 June 2009), the European Court of Human Rights in Strasbourg recognized this that state obligations to protect victims of domestic violence from torture, inhuman and degrading treatment under Article 3. 


\section{Summary}

Both reframings of domestic violence, as torture or terrorism, jolt our consciousness and, hopefully, our conscience. They uncover the deep affinities of domestic violence with categories of violence that are universally condemned as human rights violations because they deny human dignity and integrity. They shock us into recognition of the extent to which domestic violence cannot be narrowly cabined or diminished or controlled by reliance on formal equality. They help us understand that domestic violence is a form of substantive gendered inequality - a societal distribution, at both individual and structural levels, of who does and is allowed to do what to whom. Domestic violence violates the rights of women who, like men, are entitled to integrity, security and dignity. It constitutes discrimination against women by maintaining both the individual woman and women as a class in an inferior and subordinated position within their respective societies.

Consideration of domestic violence under the rubric of torture or terrorism is not designed to raise the threshold of what constitutes domestic violence. Nor does it entail the disregard for diminution of its consequences. Nor does it undermine recognition of survivor/victim's agency and resistance. Rather it provides greater space for the silenced voices of significant numbers of women by acknowledging their painful, shocking, lived experiences (WHO, 2002) and eliminating the normalization of their pain and trauma. It helps in the worldwide campaign to change the nature of the specific behavior from acceptable to unlawful (Meyerfeld, 2010: 267).

\section{References}

Anderson, K., (2008) Violence Against Women: State Responsibilities in International Human Rights Law to Address Harmful Masculinities, Netherlands Quarterly of Human Rights, 26/2, 173-197.

Copelon R., (1994) Recognizing the Egregious in the Everyday: Domestic Violence as Torture, Columbia Human Rights Law Review 25: 291.

Herman, J., (2005) Justice from the Victim's Perspective, Violence Against Women Journal, 571-601.

Johnson, M., (2995) Patriarchal Terrorism and Common Couple Violence: Two Forms of Violence Against Women, 57 Journal of Marriage and the Family 57, 2, 283-94.

Marcus, I, Reframing Domestic Violence: Terrorism in the Home in M. Fineman and R. Mykitiuk (eds), (1994) The Public Nature of Private Violence: The Discovery of Domestic Abuse, Routledge, 11-35. 
Marcus, I., Dark Numbers: Domestic Violence in Hungary, Poland, Romania, and Russia (unpublished manuscript on file with the author).

Meyersfeld, B., (2010) Domestic Violence and International Law, Oxford: Hart.

Stark, E., (2007)Coercive Control, How Men Entrap Women in Personal Life, Oxford: Oxford University Press.

WHO, (2002) World Report on Violence and Health, WHO: Geneva.

Др Изабел Маркус,

Професор Правног факултета

Државни универзитет државе Њујорк, Бафало, САД

\title{
Редефинисање концепта насиља у породици као акта тортуре или тероризма у породици
}

\begin{abstract}
Сажетак
Нови дискурс у схватању насиља у породици, које се одређује као акт тортуре или тероризма у породици, преставља атак на нашу свест и има за циљ да је пробуди. Ова нова одређења разоткривају дубоку подударност насиља у породици са категоријама насиља које су предмет опште осуде, јер представљају повреду људских права и негацију људског достојанства и интегритета. На крајње алармантан начин она нас приморавају да схватимо до које мере насиље у породици не сме бити уско или олако схваћено, укалупљено или ограничено ослањањем на формалну једнакост полова. Ова нова схватања нам помажу да препознамо да је насиље у породици облик фактичке родне неједнакости која, како на индивидуалном тако и на структуралном нивоу, представља образац социјалне дистрибуције родних улога: шта је коме дозвољено или шта ко може да чини другоме. Насиље у породици представља повреду права жена које, као и мушкарци, имају право на поштовање личног интегритета, сигурности и достојанства. Насиље у породици представља и дискриминацију жена, под којом се подразумева инфериоран и подређен положај сваке жене понаособ и свих жена, као социјалне категорије у одређеном друштву.

Успостављање новог оквира за редефинисање насиља у породици као акта тортуре или тероризма у породици није усмерено ка подизању нивоа онога што чини насиље у породици. Нови оквир нипошто не представља обезвређивање последица насиља у породици, нити има за циљ да на било који начин оспори социјално препознавање патње и отпора преживелог/
\end{abstract}


жртве. Он првенствено обезбеђује више простора да се чују ућуткани гласови великог броја жена које су биле изложене оваквим видовима насиља у породици, али представља и прилику да друштво спозна болна и застрашујућа искустава која су те жене преживеле (Светска здравствена организација, 2002) и спречи “тривијализацију” њихове патње, као и даљу трауматизацију. У светским размерама, нови оквир може да представља почетак заједничке акције која би довела до промене одређених облика понашања, који би од социјално прихватљивих постали неприхватљиви и незаконити.

Кључне речи: насиље у породици, тортура, тероризам. 